\title{
JEJAK TANTRAYANA DI SITUS BUMIAYU
}

\section{TANTRIC TRACES IN BUMIAYU}

\author{
Sondang Martini Siregar \\ Balai Arkeologi Sumatera Selatan, Demang Lebar Daun Kancil Putih, Palembang; \\ email siregarsondang@yahoo.com
}

\begin{abstract}
Abstrak. Agama Hindu Buddha mengenal aliran Tantrayana. Aliran ini bersifat gaib dan diajarkan secara lisan kepada pemeluknya. Aliran ini pernah berkembang di Nusantara dan sisa-sisa arca yang dipuja masih ditemukan di beberapa situs di Indonesia. Aliran Tantrayana juga berkembang di situs Bumiayu. Selanjutnya, permasalahan yang muncul adalah bagaimana penggambaran arca Tantrayana yang ada di Bumiayu. Tujuan penelitian ini adalah untuk mengetahui jenis dan ciri arca Tantrayana di situs Bumiayu, dan hubungannya dengan arca Tantrayana lainnya di Pulau Sumatera (Padang Lawas dan Sungai Langsat). Metode yang dipakai dalam penelitian ini adalah kualitatif yang bersifat deskriptif dengan penalaran induktif. Hasil penelitian menunjukkan bahwa awal perkembangan agama Hindu di Bumiayu berkisar pada abad ke-9 Masehi, yang selanjutnya mendapat pengaruh aliran Tantrayana. Arca dengan aliran Tantrayana digambarkan dalam bentuk menyeramkan dan memiliki hiasan tengkorak. Umat Hindu melakukan upacara Tantrayana dengan tujuan untuk melindungi daerah Bumiayu dari serangan Raja Kertanegara yang melakukan ekspedisi Pamalayu ke Sumatera pada tahun 1275.
\end{abstract}

Kata kunci: arca, Tantrayana, Bumiayu, penggambaran

\begin{abstract}
Hindu-Buddhist religion had known Tantrayana stream. Tantrayana was supernatural and had been taught orally to its adherents. This stream had ever grown in the archipelago and the remains of revered statues were found in several sites in Indonesia. Tantrayana had also developed in Bumiayu site. An important issue is how the depiction of HinduTantric statues in Bumiayu. This study aims to gain the types and characterictics of Hindu-Tantric statues in Bumiayu, and its relationship with other Tantric statues found in Sumatera (Padang Lawas and Sungai Langsat). The method used in this research is a qualitative method, by descriptive analysis and inductive reasoning. The result showed that the development of Hindu in Bumiayu began during git century, and then It had gotten Tantrayana influence. Some Hindu-Tantric statues were depicted in horrific form with skull ornaments. The aim of Hindu-Tantric follower performed their religious ceremonies was to protect Bumiayu from Kertanegara attack who did Pamalayu expedition to Sumatera in 1275.
\end{abstract}

Keywords: statue, Tantric, Bumiayu, depiction

\section{PENDAHULUAN}

Tantra berarti tenunan atau keadaan bengkok, atau sesuatu yang terus-menerus dan rangkaian yang tak terputus dalam kebiasaan agama sebagai peraturan atau upacara yang tertib. Tantra merupakan penjelmaan Dewa Trimurti dalam agama Hindu, yaitu Brahma, Wisnu, dan Siwa, tetapi dalam pelaksanaannya bergantung kepada Siwa sendiri yang mengadakan tanya-jawab kepada istrinya. Dewi Durga atau Kali, yang membuka rahasia mistik dan menetapkan peraturan agama yang diterima dan dianut oleh para pemeluknya. Selanjutnya, paham disempurnakan dan dimasukkan dalam agama Hindu maupun Buddha. Sekitar abad ke-6 Masehi kepercayaan kepada sakti dan paham Tantarayana berpengaruh baik dalam agama Hindu dan Buddha. Kedua agama memuja sakti baik dalam bentuk Dewi Laksmi ataupun Dewi Tara sebagai pemujaan yang tertinggi. Dalam paham Tantrayana, yang dipuja adalah wanita 
sebagai sumber kekuatan. Penganut Tantrayana beranggapan bahwa sakti adalah ibu alam semesta sehingga segala sesuatu berasal dari sakti dan akan kembali kepadanya (Surasmi 2007: 22).

Pada mulanya aliran Tantrayana muncul di India, yaitu pemujaan kepada Ibu di Lembah Sungai Indus. Pemujaan terhadap dewa perempuan dilakukan dengan mempersembahkan seekor domba. Di Bengal, masyarakat sudah biasa menjalankan pemujaan kepada sakti (kali) yang juga dikenal sebagai dewi kemakmuran. Pemujaan kepada sakti dan upacara-upacara Tantrayana merupakan kepercayaan India kuno. Menurut aliran Tantrayana, untuk mencapai tujuan hidup setiap orang mengucapkan mantra dan melakukan upacara gaib agar dapat bersatu dengan sakti. Dalam kitab agama Hindu digambarkan Dewi Durga (kali) dan Siwa (Mahakala) saling bercakap. Gambaran itu juga diwujudkan dalam relief di Benggala, yaitu gambaran Dewa Siwa sedang berkasih-kasihan dengan Dewi Pertiwi. Maka dalam agama Siwa terdapat aliran Tantrayana, yaitu ajaran yang bertujuan mempersatukan diri dengan Tuhan. Pemeluk Tantrayana melakukan ibadah dengan cara bernyanyi, menghisap candu, minuman keras dengan tujuan untuk mencapai mokhsa dalam waktu singkat. Percakapan antara seorang dewa dengan saktinya (Dewa Siwa dan Dewi Durga) tidak hanya diwujudkan di dalam relief, tetapi juga diwujudkan dalam bentuk lingga (dewa) dan yoni (rahim ibu) (Surasmi 2007: 22).

Magetsari berpendapat bahwa apabila aliran Tantrayana bersifat vulgar, menggunakan unsur ilmu sihir, melakukan perbuatan mabuk-mabukan dan pemujaan kepada kekuatan baik dengan tujuan jahat ataupun sebaliknya, berarti aliran Tantrayana sudah mengalami kemunduran dalam perkembangan agama. Hal ini dikarenakan Kitab Sang Hyang Kamahayanikan menyebutkan bahwa aliran Tantrayana hanyalah ajaran lisan yang disampaikan turun-temurun kepada muridmuridnya secara rahasia. Seorang murid diwajibkan belajar secara tepat dan teliti. Oleh karena itu, seorang guru harus mampu mempersiapkan dan menuntun muridnya secara benar. Tanpa bimbingan seorang guru, seorang murid akan memperoleh kesengsaraan, kegilaan, dan kematian bahkan masuk neraka, bukannya mencapai kebuddhaan. Untuk merahasiakan ajaran ini maka dalam ajaran lisan seorang harus memperoleh bimbingan guru sedangkan dalam bentuk naskah, rahasia itu harus dipertahankan dengan mempergunakan bahasa semu, yaitu mempunyai arti kiasan dan harafiah. Adapun yang dimaksud dengan arti kiasan adalah aliran diberikan dan diterangkan oleh guru kepada murid yang telah dipersiapkannya sendiri. Demikian pula dengan ajaran yang dirumuskan dalam arti harafiah adalah pokok-pokok ajaran saja, sedangkan pelaksanaannya diajarkan secara lisan (Magetsari 1997: 375).

Pada masa Sriwijaya aliran Tantrayana pernah berkembang sekitar abad ke-7 Masehi. Hal ini ditunjukkan dalam isi prasasti Telaga Batu bahwa seluruh anak negeri adalah orang-orang yang sangat baik, taat terhadap raja, maka raja membalas dengan Tantramala. Tantramala adalah rumus rahasia yang memberikan bermacammacam kebahagiaan dalam hidup di dunia maupun di akhirat (Surasmi 2007: 60-61).

Beberapa situs di Pulau Sumatera yang mendapat pengaruh aliran Tantrayana, yaitu situs Padang Lawas (Sumatera Utara), situs Padangroco dan situs Sungai Langsat (Sumatera Barat), dan situs Bumiayu (Sumatera Selatan). Situs-situs yang mendapat pengaruh Tantrayana umumnya berlatar belakang Buddha, kecuali situs Bumiayu yang berlatar belakang agama Hindu (Siregar 2001: 8-9).

Situs Bumiayu berada di Desa Bumiayu, Kecamatan Tanah Abang, Kabupaten Muaraenim. Situs Bumiayu memiliki luas sekitar 40 hektar, dikelilingi oleh Sungai Lematang beserta anakanak sungainya. Situs Bumiayu telah lama diteliti oleh peneliti, baik dari dalam maupun luar negeri. Tahun 1993 Pusat Penelitian Arkeologi Nasional melakukan penelitian di situs Bumiayu, dan menemukan gundukan-gundukan tanah yang berisikan struktur bata. Pusat Penelitian Arkeologi Nasional menamakan gundukan-gundukan tanah tersebut sesuai dengan urutan waktu penemuannya, yaitu Candi Bumiayu 1, 2, 3, 4, 5, $6,7,8,9,10$. Dari kesepuluh candi tersebut hanya Candi Bumiayu 1, 2,3 , 7 dan 8 yang telah dipugar, 
sedangkan yang lainnya masih tertimbun dalam tanah. Di dalam situs Bumiayu ditemukan kompleks percandian Bumiayu 1, 2 dan 3, dilengkapi dengan arca-arca (Ferdinandus 1993: 33-38).

Pembangunan situs Bumiayu diperkirakan berlangsung dalam dua tahapan. Tahap pertama sekitar abad ke-9 Masehi, yaitu pembangunan kompleks Candi 1 beserta arca-arca yang terbuat dari batu putih (tufa) dan pembangunan kompleks Candi 2. Pembangunan tahap kedua sekitar abad ke-13 Masehi, yaitu penambahan pilaster Candi 1 dan pembangunan kompleks Candi 3 (Satari 2002: 113-128).

Satyawati Suleiman beranggapan bahwa arcaarca tersebut bergaya seni Jawa Tengah, abad ke-9 Masehi. Hal ini dikarenakan adanya keturunan Jawa Tengah berkuasa di Sumatera dan ketika dia berkuasa turut mempengaruhi dalam pendirian bangunan candi dan pembuatan arcaarca di Sumatera. Arca-arca tersebut memiliki ciriciri, rambut keriting sampai ke bahu dan mengenakan kain panjang dengan hiasan wiru di bagian tengah kain (Suleiman 1985: 385). Arcaarca dari Candi Bumiayu memiliki kesamaan dengan arca-arca dari Jawa Tengah, diperkirakan dibuat pada abad ke-9 Masehi.

Pada masa selanjutnya, situs Bumiayu mendapat pengaruh aliran Tantrayana. Arcaarcanya digambarkan dengan raut wajah berbeda dibandingkan dengan arca-arca dari Candi Bumiayu 1. Arca-arca umumnya terbuat dari bahan tanah liat. Hal tersebut menarik diteliti untuk mengetahui bagaimana jenis dan gambaran arcaarca Tantrayana dari situs Bumiayu dan hubungannya dengan arca Tantrayana lainnya di Pulau Sumatera.

Satyawati Suleiman (1985: 26) menyatakan bahwa arca-arca Tantrayana digambarkan dalam wujud seram karena dihubungkan dengan ritual Tantrayana. Pemeluk Tantrayana melakukan pemujaan kepada dewa/raksasa untuk mencapai kelepasan (mokhsa), yaitu dengan memakai sihir, bersemadi, dan mengucapkan mantra-mantra. Upacara yang terpenting adalah melakukan upacara Bhairawa, yang dilakukan di atas ksetra. Ksetra adalah halaman kuburan, tempat jenazahjenazah dikuburkan sebelum dibakar. Tempat itu menjadi tempat menarik bagi hantu, setan, dan burung hantu. Di tempat tersebut dilakukan upacara rahasia oleh pemeluknya seperti bersemadi, menari-nari, mengucapkan mantramantra, membakar jenazah, minum darah, tertawatawa, dan mengeluarkan bunyi seperti banteng.

\section{METODE}

Metode yang dipakai dalam penulisan ini adalah metode kualitatif, dengan penalaran induktif. Metode kualitatif diterapkan untuk mengkaji arca-arca dari situs Bumiayu sehingga diketahui ciri arca aliran Tantrayana dari situs tersebut. Selanjutnya, gambaran arca-arca Tantrayana dari situs Bumiayu diperbandingkan dengan arca Tantrayana di luar situs Bumiayu seperti dari situs Padang Lawas dan situs Sungai Langsat.

\section{HASIL DAN PEMBAHASAN}

\section{Arca-arca dari Situs Bumiayu}

Arca Siwa Mahadewa dari Candi Bumiayu 1

Di situs Bumiayu ditemukan arca Siwa Mahadewa. Arca Siwa ini terlihat dalam posisi duduk. Ukuran tinggi secara keseluruhan $62 \mathrm{~cm}$, sedangkan tinggi arca $51 \mathrm{~cm}$, lebar $36 \mathrm{~cm}$, tebal $24 \mathrm{~cm}$, dan tebal sandaran $5 \mathrm{~cm}$. Arca memiliki 4 (empat), kedua telapak tangan di bagian depan sudah pecah. Arca yang dibuat dari batu putih (limestone) ini mempunyai sandaran yang berbentuk setengah lonjong tanpa memiliki hiasan. Sirascakra dipahat polos, berbentuk bulat telur sampai di belakang bahu. Asananya berupa padmasana ganda berbentuk segiempat polos di bagian bawah, sementara lapik bagian atas berhias pola segienam. Mahkota yang dikenakan berbentuk jatamakuta berhias pola lengkungan dengan untaian manik-manik di dalamnya. Arca tidak memiliki anting, mengenakan ikat kepala (jamang) namun sudah pecah, mengenakan dua kalung berbentuk untaian manik-manik dan jumbai, tidak memiliki antingan (Siregar 2005: 7).

Arca Siwa Mahadewa merupakan dewa yang dipuja umat Hindu. Dewa Siwa merupakan dewa yang paling ditakuti oleh pemeluknya karena 
memiliki kuasa merusak dan menghancurkan. Dewa Siwa juga diwujudkan di dalam bentuk lingga dan saktinya (pasangannya) diwujudkan dengan yoni (lihat gambar 1). Di situs Bumiayu ditemukan beberapa lingga dan yoni. Hal ini menunjukkan bahwa kedua dewa tersebut sangat dipuja oleh pemeluknya pada masa itu. Jadi ada beberapa lokasi aktivitas keagamaan pada masa itu, yaitu pemujaan kepada Dewa Siwa yang diletakkan di bagian tengah bangunan candi. Lingga dan yoni juga dipuja oleh pemeluknya, ditaruh di tempat lain, tetapi masih berada di kompleks percandian Bumiayu.

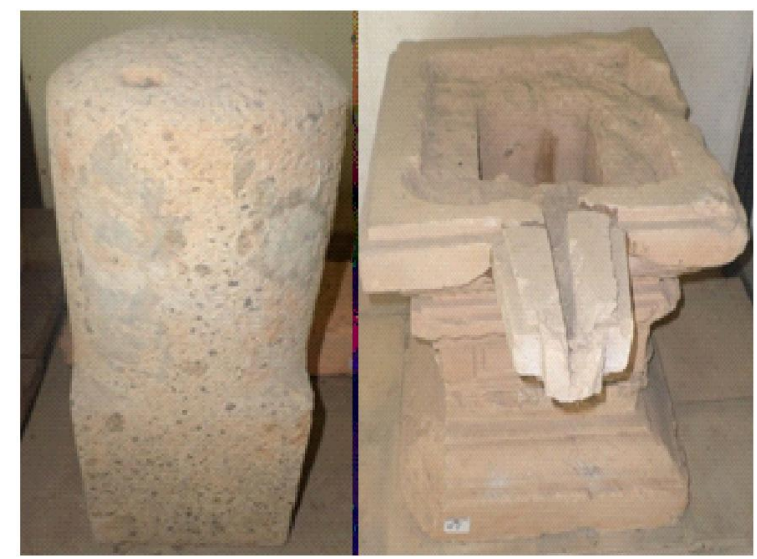

sumber: dok. pribadi

Gambar 1. Lingga dan yoni dari Candi Bumiayu 1

Arca Tokoh 1 dari Candi Bumiayu 1

Arca diwujudkan dalam sikap duduk di atas padmasana ganda berbentuk segi empat. Bahan arca adalah batu putih (limestone). Arca memiliki sandaran arca dan di bagian belakang kepala terdapat sirascakra berbentuk lonjong. Sikap kedua tangan berada di atas pangkuan, telapak tangan kiri di bawah telapak tangan kanan, dan di atas telapak tangan kanan terdapat bunga padma mekar. Arca mengenakan mahkota yang merupakan pilinan rambutnya sendiri (jatamakuta) yang tinggi dengan hiasan simbar. Jamang (ikat kepala) berbentuk pita lebar berhias deretan manik-manik dihiasi lima simbar dengan pola sulur. Arca mengenakan dua kalung berhias sulur dan manik-manik. Hiasan telinga berupa ratna kundala dengan pola sulur. Gelang tangan berbentuk pita dengan deretan manik-manik berhias simbar dengan pola sulur. lkat pinggang yang dikenakan berupa deretan manik-manik yang bagian depannya terdapat semacam gesper berhias pola sulur. Arca memiliki dua gelang kaki polos, demikian juga dengan gelang tangan. Arca ini tidak memakai uncal, sedangkan sampur yang dikenakan berbentuk polos berlipatlipat, tidak ada simpul. Kain yang dikenakan panjang sampai ke betis dan berhias bunga dengan pola geometris, tepinya berhias deretan bulatan dengan pola sulur. Selain hiasan tersebut masih terdapat sumping di belakang telinga. Asananya berbentuk memanjang ke depan sehingga lebih tebal dari badan arca. Hiasan terdapat pada asana berupa pola bunga dan sulur. Arca ini berukuran tinggi keseluruhannya $62 \mathrm{~cm}$, tinggi arca $50 \mathrm{~cm}$, lebar $36 \mathrm{~cm}$, dan tebal $4,5 \mathrm{~cm}$ (Siregar 2005: 9).

Berdasarkan penggambaran arca tokoh 1 adalah perwujudan dari arca dewa (lihat gambar 2). Hal ini dikarenakan arca tokoh 1 memiliki ciri arca kedewaan, yaitu mengenakan mahkota jatamakuta, memiliki sandaran arca di bagian belakang badannya, dengan hiasan prabhamandala (lidah api). Begitu pula arca memiliki sandaran di belakang kepala berbentuk lonjong (sirascakra). Ciri-ciri tersebut

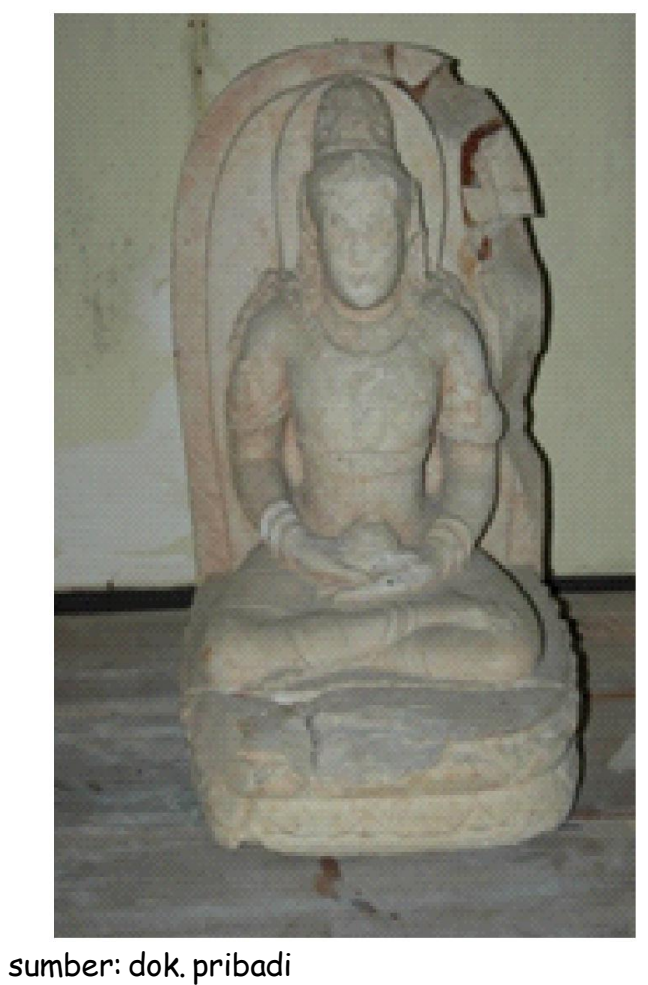

Gambar 2. Arca yokoh 1 dari Candi Bumiayu 1 
menunjukkan bahwa arca tokoh 1 bukanlah arca perwujudan manusia, tetapi perwujudan dewa yang dipuja oleh umat Hindu.

\section{Arca Leluhur dari Candi Bumiayu 1}

Arca digambarkan berbadan gemuk, ditemukan di sebelah timur bangunan Candi Bumiayu 1 dalam keadaan retak pada bagian dada dan sandaran atas. Bahan yang digunakan untuk membuat arca ini adalah limestone. Penggambaran arca ini dalam sikap duduk padmasana di atas asana yang berupa lapik polos setengah bulat. Mempunyai tangan dua yang terletak di atas pangkuan, telapak kiri di bawah telapak tangan, yang di atasnya terdapat bunga mekar. Sandaran tepi berjenjang, bagian bawah lebar, kemudian mengecil berbentuk lonjong, polos. Sirascakra digambarkan polos berbentuk bulat telur sampai ke belakang bahu. Pada kedua bahu terdapat rambut ikal menjurai. Hiasan yang dikenakan terdiri dari mahkota berupa jatamakuta, jamang (ikat kepala) berbentuk pita lebar polos, berhias tiga simbar dan memakai sumping. Kalung yang terdapat arca ini berjumlah dua yang berhias pola sulur tetapi dalam keadaan aus. Hiasan telinga berbentuk bulatan dan ujungnya berhias jumbai. Hiasan lain adalah gelang tangan berupa pita dengan deretan manikmanik berhias simbar dengan pola sulur. Ikat pinggang yang dikenakan berbentuk pita berhias,

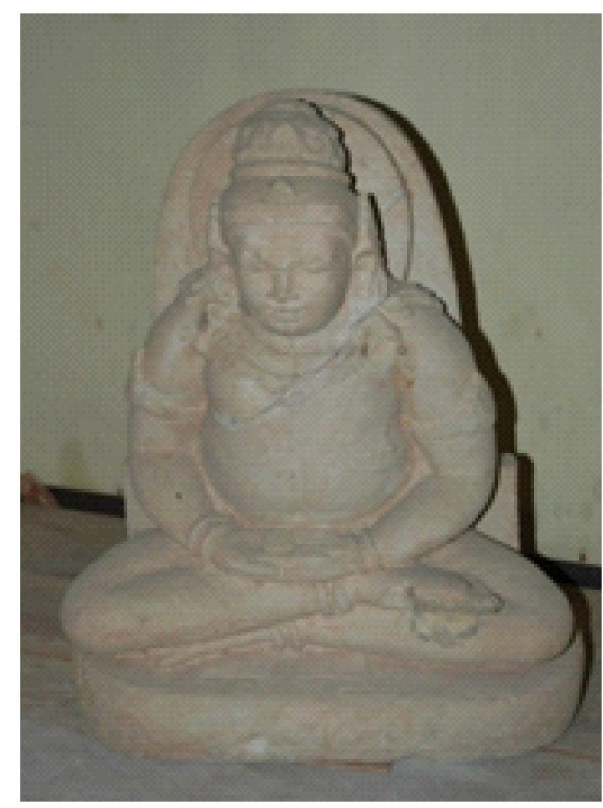

sumber: dok. pribadi

Gambar 3. Arca leluhur dari Candi Bumiayu 1 tetapi aus berlekuk-lekuk. Gelang berupa untaian manik-manik bersusun dua, sedangkan gelang kaki ada dua polos. Arca ini tidak memakai uncal, tetapi memakai sampur yang tidak jelas, karena hanya tampak bagian ujungnya yang menjurai di asana dan bagian yang menempel di paha, berhias geometris tetapi agak aus. Memakai kain yang panjangnya sampai betis dan berhias pola bunga, tetapi sudah aus (Siregar 2005: 9).

Arca ini merupakan perwujudan tokoh manusia dan tidak menunjukkan ciri arca kedewaan (lihat gambar 3). Arca tidak memiliki lingkaran di belakang badannya (prabhamandala). Arca ini kemungkinan adalah arca leluhur dari pejabat/raja yang berkuasa pada masa itu, dan pejabat tersebut terlibat dalam pendirian bangunan candi di situs Bumiayu.

Arca Pendeta dari Situs Bumiayu

Di situs Bumiayu ditemukan tokoh pendeta dalam dua perwujudan. Di Candi Bumiayu 1 ditemukan tokoh pendeta dalam wujud arca Agastya dalam posisi berdiri, sedangkan di Candi Bumiayu ditemukan tokoh pendeta dalam posisi wujud manusia. Hal ini cukup menarik karena Agastya merupakan perwujudan Dewa Siwa Mahayogi yang menjadi seorang pendeta, penyebar ajaran Hindu di India Selatan. Arcanya ditemukan dalam dua wujud, yaitu sebagai arca Agastya dan arca pendeta.

Arca Agastya yang digambarkan berdiri, bertangan dua dan berjanggut panjang (gambar 4). Agastya ini termasuk dalam kelompok Dewa Pariwara (pendamping) bersama Ganesya dan Durga Mahisasuramardhini. Dalam konstelasi arca pada candi Hindu, Agastya diletakkan pada salah satu sisi ruang atau relung candi utama (induk), yaitu pada sisi selatan. Adapun ciri-ciri Agastya dari Bumiayu ini antara lain membawa kamandalu (kendi), aksamala (tasbih), berperut buncit, dan memiliki trisula. Arca Agastya dari Candi Bumiayu 1 digambarkan dalam posisi berdiri di atas padmasana ganda berbentuk segiempat membulat, bagian atas berhias pola geometris segienam yang menggambarkan bentuk biji teratai. Asana ini terdiri dari dua bagian, satu bagian menjadi satu dengan tokoh arca, sedangkan bagian lainnya berupa asana yang jika 
digabungkan membentuk rongga. Arca dipahatkan bertangan dua, tangan kanan berada di depan perut memegang aksamala dan tangan kiri lurus ke bawah memegang kendi (kamandalu). Sandaran arca merupakan bentuk sisi sejajar, polos yang pecah pada bagian puncaknya. Sirascakra tidak ditemukan pada arca Agastya ini. Ukuran arca adalah tinggi (keseluruhan) $69 \mathrm{~cm}$, lebar $29 \mathrm{~cm}$, tinggi lapik $14 \mathrm{~cm}$, dan tebal sandaran $3,5 \mathrm{~cm}$. Mahkota dan jamang yang terdapat pada arca pecah sehingga tidak teridentifikasi. Meskipun demikian terlihat adanya sumping di bagian telinganya. Pada kedua bahu terdapat rambut ikal menjurai. Hiasan lain yang dikenakan adalah kalung berhias pola bunga dan sulur, sedangkan hiasan telinga membentuk bulatan dengan jumbai. Gelang lengan berupa pita polos, berhias simbar dengan sulur. Ikat pinggang lebar dengan hiasan yang tidak jelas, sedangkan ikat pinggul berhias semacam gesper tetapi sudah aus. Arca memiliki dua gelang tangan dan dua gelang kaki (Siregar 2005: 9).

Arca pendeta dari Candi Bumiayu 3 memiliki rambut yang diikat ke atas, berjenggot, mata menghadap ke bawah (lihat gambar 5). Badannya

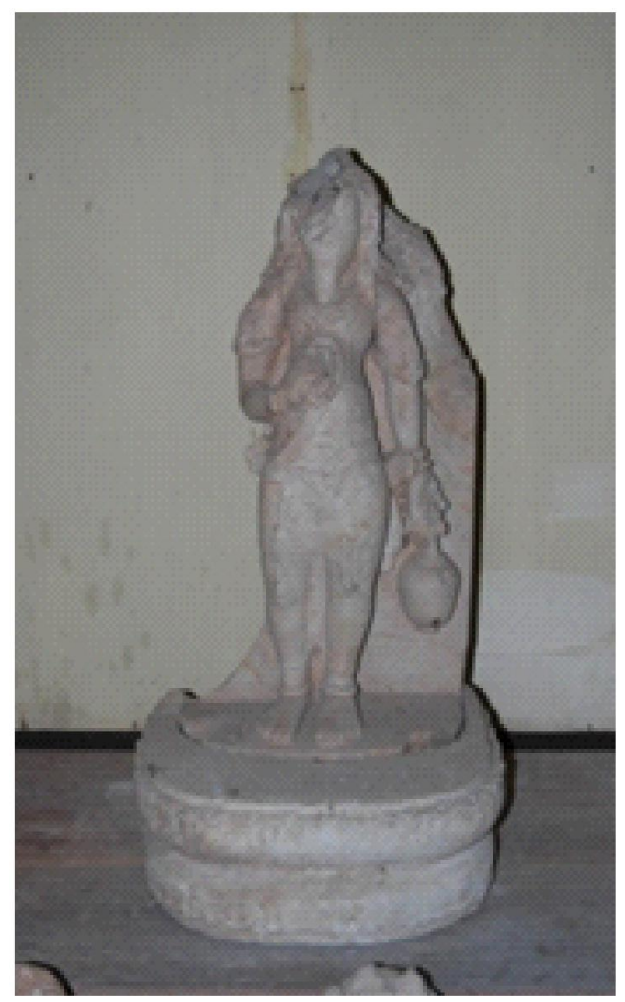

sumber: dok. Balar Sumatera Selatan

Gambar 4. Arca Agastya dari Candi Bumiayu 1

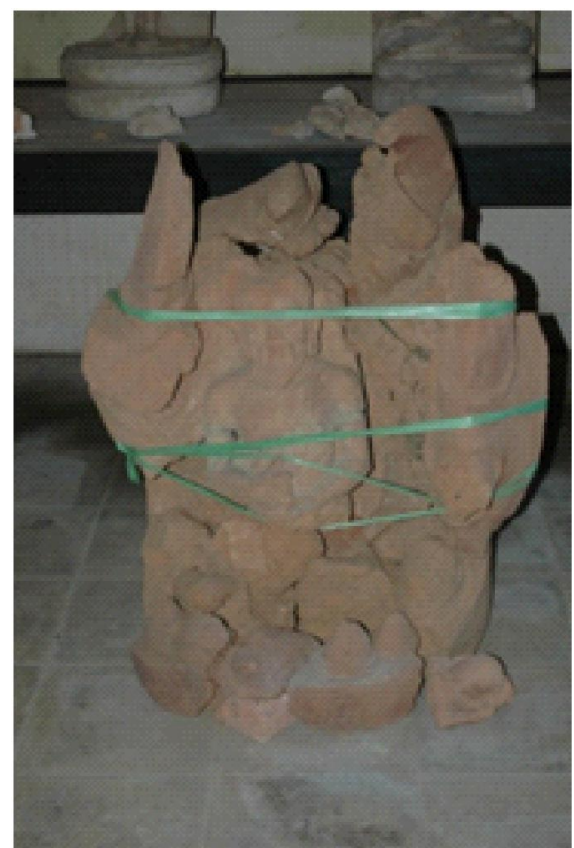

sumber: dok. Balar Sumatera Selatan

Gambar 5. Arca pendeta dari Candi Bumiayu 3

mengenakan upavita berbentuk tali polos yang diselempangkan dari bahu kiri ke pinggul kanan. Arca pendeta ini berada di dalam mulut makara Candi Bumiayu 3 (Siregar 2005: 14).

Arca-Arca Makhluk Gana dari Situs Bumiayu

Arca makhluk gana dari situs Bumiayu ditemukan dalam bentuk bervariasi, yaitu arca makhluk gana sebagai arca stambha dari Candi Bumiayu 1 terbuat dari bahan batu granit dan arca makhluk gana sebagai hiasan pipi tangga dan panil pada Candi Bumiayu 3 terbuat dari bahan tanah liat (lihat gambar 6).

Arca makhluk gana dalam bentuk arca stambha merupakan perwujudan 3 tokoh yang saling mendukung, yaitu gajah, gana, dan singa, dalam posisi gana menunggangi gajah dengan menggendong singa. Pola gajah dan singa ini merupakan pola yang populer di Indonesia dan India Timur antara abad ke-10-12 Masehi. Pada belalai gajah terdapat setangkai bunga dan daundaunan, serta mempunyai dua gading. Arca memiliki tinggi $55 \mathrm{~cm}$, lebar $18 \mathrm{~cm}$, dan tebal 17,5 $\mathrm{cm}$. Ada kemungkinan arca ini menggambarkan karivairi suatu bentuk yang sangat populer di wilayah Orissa sekitar abad ke-11-12 Masehi. Dalam sistem percandian yang dikenal di India biasanya terdapat bangunan menara di setiap 
sudut dekat pagar. Di atas menara-menara inilah biasanya ditempatkan suatu arca (biasanya berupa binatang singa atau gajah) stambha sebagai hiasan puncaknya. Adanya kemungkinan arca stambha ini juga berasal dari suatu menara yang mungkin didirikan di sekitar Candi Bumiayu 1 tidak menutup kemungkinan bahwa di sinilah lokasi semula arca stambha tersebut (Siregar 2005: 11).

Bambang Budi Utomo memperkirakan bahwa arca stambha adalah arca candrasangkala yang menjadi petunjuk pertanggalan situs Bumiayu. Arca singa adalah pertanggalan angka 8 , gana adalah angka 1 dan gajah menunjukkan angka 8 , sehingga apabila digabung menjadi angka 818 Saka atau 896 Masehi (Utomo 1994: C6-1-11).

Arca makhluk gana sebagai hiasan pipi tangga Candi Bumiayu 3 memiliki ukuran tinggi arca $51 \mathrm{~cm}$, lebar $45 \mathrm{~cm}$, dan tebal 13,5 cm. Arca tersebut digambarkan dalam posisi berdiri dengan kedua tangan terangkat ke atas dan kaki mengangkang. Jari-jari terbuka dan telapak tangan menghadap ke atas, mata melotot memiliki alis, hidung besar. Nampak mulutnya terbuka dengan deretan gigi runcing menutup rahang bawah. Rambut lurus disisir ke belakang kepala, memiliki telinga lebar, subang berbentuk cincin, berjenggot dan mahkota berupa tengkorak yang diuntai dengan sulur-suluran. Hiasan kalung berupa tengkorak, mengenakan dua gelang di tiap tangan, yang berbentuk tali polos dengan perut buncit, dan buah dada menonjol. Arca makhluk gana ini diletakkan pada pipi tangga Candi Bumiayu 3 (Siregar 2005: 14).

Arca makhluk gana juga digambarkan sebagai hiasan panil Candi Bumiayu 3 (lihat gambar 7). Arca-arca digambarkan dalam raut wajah yang bervarisi, menjadi hiasan sudut dari panil bata candi. Arca-arca makhluk gana digambarkan dengan wajah melongo dan mata melotot (Siregar 2002: 2). Penggambaran makhluk gana dalam berbagai variasi di situs Bumiayu menunjukkan keberadaannya sangat penting untuk Candi Bumiayu 3. Di dalam bangunan suci terdapat arca-arca penjaga bangunan suci, arca makhluk gana adalah arca pelindung bangunan suci (Susanto 1998: 15-24). Arca makhluk gana berfungsi sebagai penolak bahaya terhadap musuh yang ingin menghancurkan bangunan Candi Bumiayu 3.

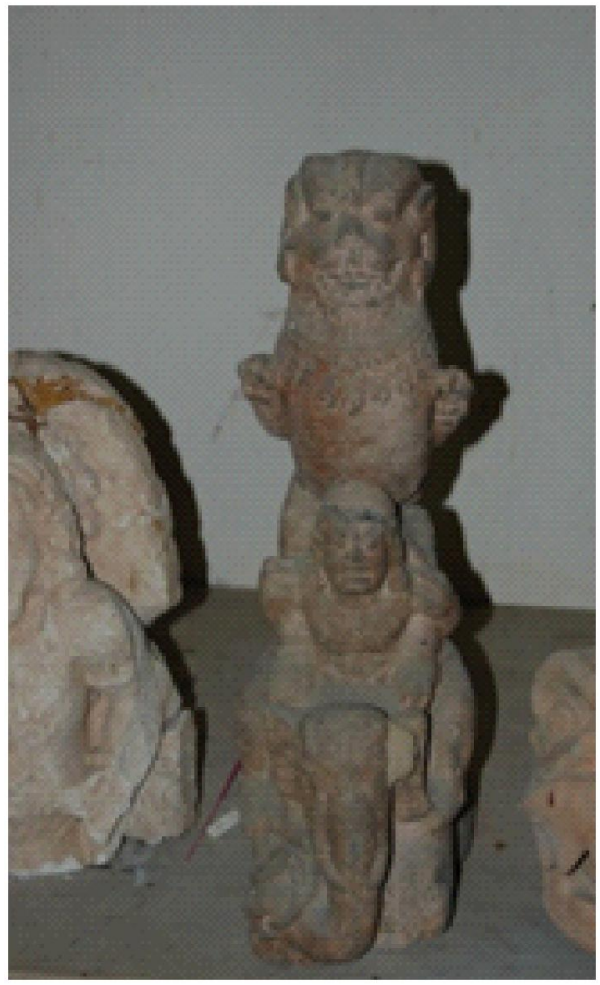

sumber: dok. pribadi

Gambar 6. Arca Stambhadari Candi Bumiayu 1

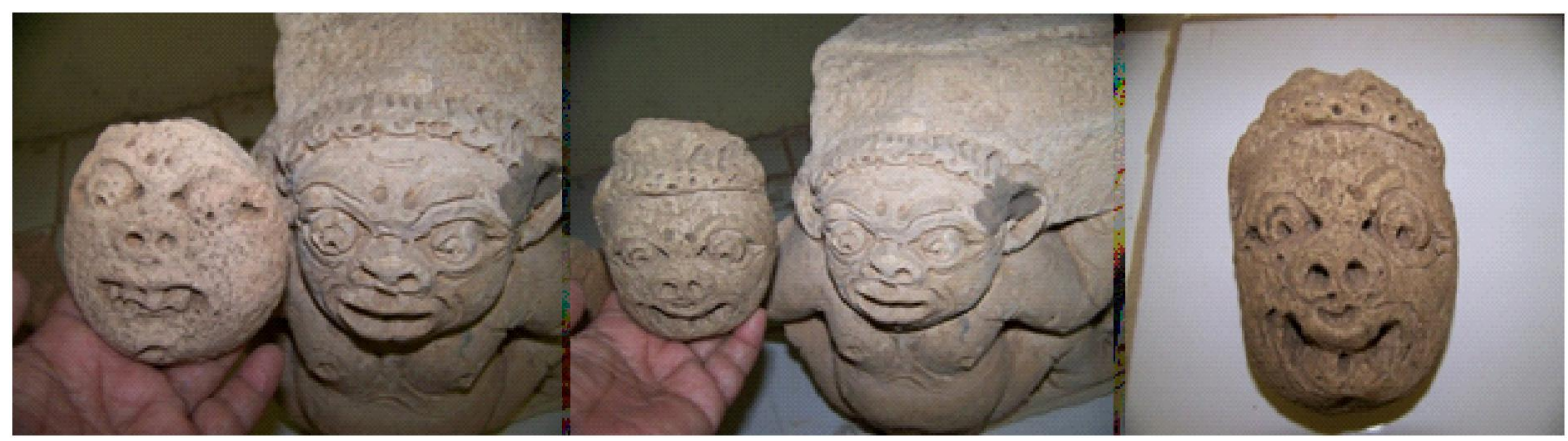

sumber: dok Balar Sumatera Selatan

Gambar 7. Arca-arca makhluk gana menjadi hiasan panil candi Bumiayu 3 
Arca Nandi

Di situs Bumiayu banyak digambarkan arcaarca binatang seperti burung nuri, kura-kura, anjing, buaya, ular, gajah, singa, dan nandi (Budisantoso 2000: 13). Akan tetapi, arca singa dan nandi digambarkan sendiri, sedangkan arcaarca binatang lainnya merupakan bagian hiasan panil bangunan candi. Arca nandi adalah binatang lembu (sapi), terbuat dari bahan batu putih (limestone). Arca nandi merupakan kendaraan (vahana) dari Dewa Siwa. Arca dalam posisi mendekam dengan kedua kaki berlipat di atas lapik berbentuk segiempat. Hiasannya berupa kalung dengan bandul genta-genta kecil. Arca mengenakan hiasan kepala. Pada bagian moncongnya terdapat untaian manik-manik yang berfungsi sebagai pengikatnya. Arca ini berukuran panjang $85 \mathrm{~cm}$ dan tinggi $35 \mathrm{~cm}$, sedangkan ukuran lapik arca memiliki panjang $70 \mathrm{~cm}$, lebar $37 \mathrm{~cm}$, dan tebal 4,5 cm (Siregar 2005: 11).

\section{Fragmen Badan Dewi Bhairawi}

Di Candi Bumiayu 3 ditemukan fragmen badan arca Dewi Bhairawi, sayangnya kepalanya sudah hilang (lihat gambar 8). Ukuran arca adalah tinggi $44 \mathrm{~cm}$, lebar $48,5 \mathrm{~cm}$, dan tebal $42 \mathrm{~cm}$. Arca tersebut digambarkan mengenakan upavita berupa hiasan enam kepala tengkorak yang diuntai dari bahu kiri sampai ke pertengahan perut. Kedua buah dadanya menonjol, tangan kanannya patah, sedangkan tangan kirinya dilipat ke bahu kiri dengan jari-jari tangan terbuka, telapak tangan menghadap ke depan, hanya jari jempol yang masih utuh, keempat jari lainnya telah patah. Kelat bahu pada tangan kiri dihias dengan kepala tengkorak dan untaian biji mutiara. Di bagian belakang badan arca terdapat sambungan upavita dengan hiasan empat kepala tengkorak. Arca Dewi Bhairawi merupakan sakti (pasangan) dengan Dewa Bhairawa, yang ditemukan pada Candi Bumiayu 3 (Siregar 2005: 13).

Selain arca Bhairawi ditemukan juga kepala arca Siwa Bhairawa dari Candi Bumiayu 3. Sayang, kepala arca Siwa ini telah hilang, meskipun demikian data tentang arca tersebut masih tercatat, yaitu ukuran kepala arca, tinggi $23 \mathrm{~cm}$, lebar 14,5 $\mathrm{cm}$, dan tebal $18 \mathrm{~cm}$. Kondisi alis, hidung, dan mulut arca sudah aus. Matanya melotot, dengan memiliki bulu mata, dan mengenakan jatamakuta, yaitu rambut ikal disusun ke ujung dahi. Telinganya panjang dengan hiasan subang berbentuk bulat hati.

Di tepi Sungai Lematang ditemukan prasasti emas (suwarnnapattra). Berdasarkan paleografi, prasasti ini diperkirakan berasal dari abad ke-1012 Masehi. Prasasti ditulis pada dua sisi, isinya berkaitan dengan mantra ajaran agama Hindu seperti dengan kata prthiwi dan pageni (Kartoatmodjo 1993: C6-3). Prthiwi juga merupakan sakti (pasangan) Siwa Mahadewa. Jadi diperkirakan dahulu di situs Bumiayu telah dilaksanakan pemujaan kepada Dewi lbu. Hal ini didukung juga dengan ditemukannya arca Bhairawi di Candi Bumiayu 3.

\section{Kepala Arca Raksasa dari Candi Bumiayu 3}

Di situs Bumiayu ditemukan 3 kepala arca raksasa (dua arca memiliki wajah sama). Arcaarca tersebut diperkirakan adalah dwalapara, yaitu

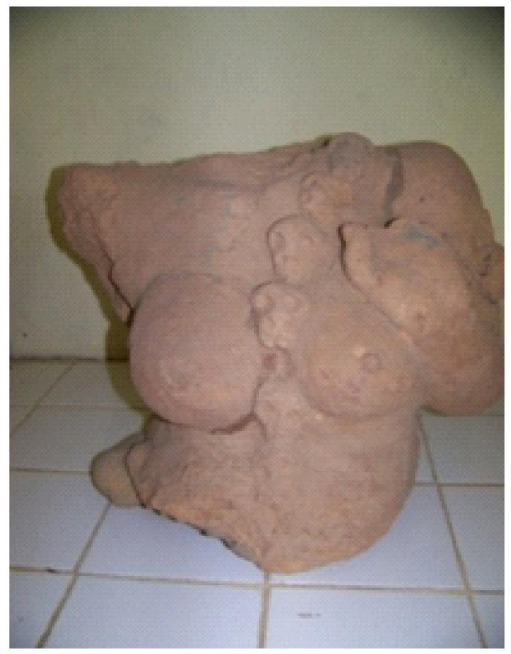

sumber: dok Balar Sumatera Selatan

Gambar 8. Badan arca Dewi Bhairawi dari Candi Bumiayu 3

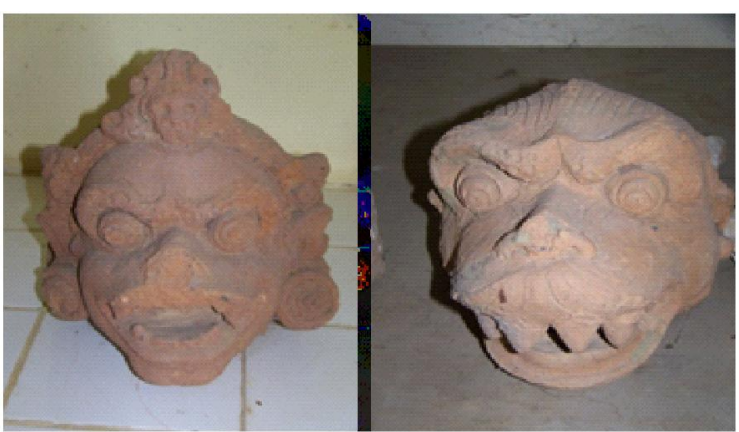

sumber: dok Balar Sumatera Selatan

Gambar 9. Arca dwalapara dari Candi Bumiayu 3 
arca penjaga bangunan suci (lihat gambar 9). Selain arca dwalapara juga ditemukan arca singa, kepala kala, dan makhluk gana (Susanto 1998: 15-24). Arca dwalapara dari Candi Bumiayu 3 digambarkan dalam raut wajah yang seram, memiliki mata melotot, bertaring, dan memiliki hiasan tengkorak di atas dahinya.

\section{Situs-situs di Sumatera yang Mendapat Pengaruh Aliran Tantrayana}

Bangunan-bangunan kuno di Padang Lawas hampir semuanya terdiri dari biaro-biaro dan stupa-stupa yang berhubungan dengan agama Buddha Wajrayana, yaitu suatu aliran dari agama Buddha yang mempunyai sifat-sifat keraksasaan. Di dalam situs Padang Lawas ditemukan arca maupun relief yang menggambarkan wajah-wajah yang menyeramkan dan prasasti singkat yang bertuliskan mantra-mantra aliran Tantris (Suleiman 1985: 26).

\section{Situs Padang Lawas}

Di situs Padang Lawas ditemukan prasasti Aek Sangkilon dan prasasti Tandihet. Prasasti Aek Sangkilon berisi upacara yang ditujukan kepada arca Yamari yang mempunyai delapan muka, 24 mata, dan untaian tengkorak. Yamari adalah dewa terpenting dalam aliran Tantrayana, sekarang arca ini telah hilang. Prasasti Tandihet berisi tentang bunyi suara orang tertawa. Salah satu ritual aliran Tantrayana adalah membunyikan suara pada saat melaksanakan upacara keagamaan. Selain prasasati, di situs Padang Lawas juga ditemukan arca Heruka dari Biaro Bahal II. Arca digambarkan menari di atas jenazah, tangan kanan di atas kepala memegang wajra, tangan kiri diletakkan di dada memegang mangkuk tengkorak dan sebuah tengkorak yang dijepitkan di bawah lengan kiri. Selempang tengkorak menghiasi badan. Muka arca tampak sudah aus, diduga di kepala terdapat hiasan arca Aksobya kecil. Di Biaro Bahal II ditemukan arca kecil, yang diduga adalah perwujudan Bhairawi. Arca memiliki rambut keriting, beranting-anting bundar, dengan badan dihiasi selempang untaian tengkorak. Tangan kirinya memegang mangkuk, tengkorak berada di hadapan dada, dan tangan kanannya diletakkan di pinggang sambil memegang wajra dan pisau. Kakinya berdiri di atas jenazah. Arca ini mungkin dulu dihiasi lapisan emas. Di halaman Biaro Pamutung ditemukan dua kepala arca yang merupakan sepasang bhairawa/ bhairawi. Mereka mempunyai mata terbelalak, dengan kening yang membentuk air muka menunjukkan amarahnya. Dari mulut mereka keluar sepasang taring. Tidak diketahui di manakah tempat asal kedua arca tersebut. Kemungkinan mereka bertempat di atas batur pendopo yang terdapat di depan Biaro induk tersebut. Pada batur terbawah candi induk Biaro Bahal 1 terdapat relief raksasa yang sedang menari dan mengenakan kain yang ditarik ke atas lutut, dengan lipatan kain yang berada di tengah. Perhiasan badan berupa subang, gelang, kelat bahu, dan gelang kaki. Tangan kanan memegang senjata, tangan kiri memegang sebuah benda lain yang tidak jelas bentuknya dan mempunyai rambut keriting (Suleiman 1985: 23-28).

Peninggalan di Padang Lawas membuktikan bahwa antara abad ke-13-14 Masehi, Buddha Tantrayana berkembang. Bangunan di Padang Lawas dinamakan Biaro. Biaro 1 dibangun abad ke-11-12 M. Pada Biaro Bahal 2 ditemukan arca Heruka dengan tinggi $118 \mathrm{~cm}$. Heruka adalah arca yang paling mengerikan dalam agama Buddha, karena sifatnya menghancurkan. Atribut arca Heruka adalah vajra (kilat disertai petir) pada tangan kanan dan mangkuk tengkorak pada tangan kiri. Tangkai khatvangga (trisula dihiasi dengan tengkorak-tengkorak, kepala manusia, dan lainlain) yang dipakai pada badannya. Tengkorak menghiasi kepala dan dadanya. Salah satu bentuk upacaranya adalah dengan tertawa hebat yang dipahatkan dalam salah satu prasastinya "hahahahhahhumhum" (Suleiman 1985: 29).

\section{Situs Rambahan (Sumatera Barat)}

Di situs Rambahan ditemukan arca Amoghapasa. Arca Amoghapasa adalah perwujudan Raja Adityawarman. Arca ini dikirim oleh Raja Kertanegara dari Kerajaan Singhasari pada tanggal 22 Agustus 1286, sebagai hadiah untuk Tribhuwanaraja, raja Melayu di Dharmasraya pada tahun 1286 Masehi. Arca digambarkan dengan 14 (empat belas) pengikut Amoghapasa. 
Empat orang berdiri di kedua sisi dengan sikap tubuh menengadah sambil menghormat dan memuliakan Amoghapasa, sedangkan sepuluh lainnya duduk di atas padma. Pada bagian bawah terukir tujuh ratna berupa lambang-lambang buddhisme, yaitu stupa, cakra, tara, boddhisatwa, kijang, dan gajah. Di bawah lapik arca dipahatkan empat baris tulisan dengan aksara Jawa Kuna dan memakai dua bahasa yaitu bahasa Melayu Kuna dan bahasa Sansekerta (Utomo 2011: 92).

\section{Situs Padangroco (Sumatera Barat)}

Di situs Padangroco ditemukan arca Bhairawa pada tahun 1930. Arca Buddha Bhairawa yang merupakan perwujudan dari raja Melayu bernama Adityawarman. Adityawarman merupakan bangsawan Majapahit dan kemudian berkuasa di Sumatera (Utomo 2011: 88). Arca terbuat dari batu andesit, dengan ukuran 4,41 meter. Arca digambarkan berdiri di atas jenazah dengan lapik yang berhiaskan tengkorak. Makutanya berbentuk umbi dan ada hiasan arca Aksobya kecil. Arca memakai jamang serta hiasan telinga seperti yang dipakai arca-arca Majapahit. Selain itu, ia memakai anting-anting, gelang berbentuk ular pada lengan dan tangannya, seperti yang biasa dikenakan arca-arca dwarapala. Sarungnya berpola tengkorak dengan pinggiran bawahnya sampai ke lutut dan kaki telanjang. Arca memakai ikat pinggang dengan ikatannya berhiaskan manik serta hiasan permata berbentuk kala. Di belakang kepala, yaitu di pundaknya terdapat nimbus yang menyala. Ajaran yang berkembang di Sumatera pada masa itu adalah ajaran Buddha. Ajaran ini pada umumnya dihubungkan dengan sikap sabar dan perdamaian terhadap sesama umat manusia. Akan tetapi, pada masa Adityawarman, ajaran ini seolah-olah menjadi agresif dan penuh amarah kepada sesama umat manusia, sebagaimana digambarkan dalam arca Bhairawa yang bersifat demonis (Suleiman 1985: 29).

Pada tahun 1343, Raja Adityawarman membuat prasada untuk merenovasi Candi Jago yang dahulu ditujukan untuk Wisnuwardana di Jawa Timur. Setelah itu, Adityawaraman ke Sumatera dan menjadi raja Melayu tahun 1347 Masehi. Ketika dia berkuasa, Raja Adityawarman memerintahkan untuk membuat arca sangat besar dalam penjelmaannya sebagai Bhairawa. Di Pagaruyung banyak inskripsi peninggalan Raja Adityawarman. Salah satu inskripsi berisikan pendirian makdis pada tahun 1375 Masehi. Di dalam inskripsi disebutkan adanya upacara penyucian berdarah yang dijalankan oleh raja yang dikultuskan menjadi Bhairawa. Raja yang dikultuskan itu adalah Adityawarman yang menyucikan dirinya menjadi Dewa Bhairawa (Utomo 2011: 89).

\section{Aliran Tantrayana di Sumatera}

Aliran Tantrayana pernah berkembang di Pulau Sumetera, yaitu di situs Padang Lawas, situs Rambahan dan Padangroco, dan situs Bumiayu. Hal ini dibuktikan dengan ditemukannya arca-arca Tantrayana yang digambarkan dengan raut wajah seram dan memiliki hiasan tengkorak pada badannya. Pemeluk aliran Tantrayana di situs Padang Lawas memuja Bhairawa Heruka. Raja Adityawarman mewujudkan dirinya sebagai Bhairawa Kalacakra dan Raja Kertanegara diwujudkan dalam arca Bhairawa Heruka. Rajaraja diwujudkan sebagai Bhairawa dengan maksud mereka sebagai dharmapala/pelindung agama dalam wujud menakut-nakuti untuk menghukum musuh agamanya (Suleiman 1985: 28). Penggambaran ini juga bertujuan untuk melindungi raja dan wilayah kekuasaannya dari serangan musuh.

Di situs Bumiayu juga ditemukan arca-arca Tantrayana. Pada Candi Bumiayu 3 ditemukan arca Siwa Bhairawa beserta saktinya. Keberadaan arca-arca ini menunjukkan dahulu di situs Bumiayu berlangsung pemujaan kepada Dewa Bhairawa dan Dewi Bhairawi. Dahulu diperkirakan upacara ritual Tantrayana di Bumiayu dipimpin oleh seorang raja/pejabat yang berkuasa pada masa itu. Pejabat tersebut diwujudkan dalam bentuk arca. Di Candi Bumiayu 1 ditemukan arca leluhur yang diperkirakan adalah perwujudan raja/pejabat yang berkuasa pada masa itu. Raja/pejabat tersebut merupakan pendiri bangunan candi di situs Bumiayu. 
Keberadaan arca Bhairawa dan Bhairawi di Candi Bumiayu 3 menunjukkan bahwa Candi Bumiayu 3 merupakan bangunan suci yang ditujukan untuk ritual Tantrayana, dengan pusat pemujaan kepada Dewa Bhairawa dengan saktinya (Bhairawi).

Arca Tantrayana lainnya dari situs Bumiayu adalah dua arca penjaga candi (dwalapara) dari Candi Bumiayu 3. Kedua arca dwalapara tersebut digambarkan dengan mata melotot, memiliki hiasan tengkorak di atas kepalanya. Arca dwapalara dari Candi Bumiayu diperkirakan dahulu diletakkan di depan pintu gerbang Candi Bumiayu 3. Arca pendeta dari Candi Bumiayu 3 juga memiliki hiasan tengkorak, arca pendeta menjadi hiasan pada mulut makara Candi Bumiayu 3.

Arca singa dari situs Bumiayu digambarkan bervariasi. Arca singa dari Candi Bumiayu 1 lebih sederhana hiasannya. Arca singa dari Candi Bumiayu 3 tampak dalam posisi memegang ular, di bawah badannya terdapat pahatan arca kurakura. Fungsi dari arca singa adalah penjaga bangunan candi, dahulunya diletakkan di depan pintu masuk bangunan candi. Arca singa dari situs Bumiayu memiliki kemiripan dengan arca singa dari situs Padang Lawas.

Arca makhluk gana dari situs Bumiayu ditemukan dalam bentuk yang bervariasi, yaitu pada Candi Bumiayu 1 dan Candi Bumiayu 3. Makhluk gana dipahat sebagai arca stambha, dan sebagai hiasan pipi tangga dan hiasan panil bangunan candi. Makhluk gana yang menjadi hiasan panil ditemukan dengan wajah seram dan mata melotot. Penggambaran rupa makhluk gana tersebut dihubungkan dengan bangunan Candi Bumiayu 3 sebagai bangunan suci bagi pemeluk aliran Tantrayana. Penggambaran wajah tersebut merupakan ekspresi muka para penganut Tantrayana dalam mengucapkan mantra, tertawa, dan mengeluarkan bunyi seperti banteng.

Arca makhluk gana juga ditemukan di Biaro 2, situs Padang Lawas (Sumatera Utara). Arca dalam posisi menari. Para penganutnya melakukan ritual Tantrayana dengan memuja Dewa Heruka, arcanya dipahat pada relief bangunan Biaro Bahal 2. Makhluk gana dari Padang Lawas disebut Yaksa, ada 6 relief yaksa dipahat pada Biaro Bahal 1. Yaksa digambarkan dalam posisi menari, merupakan salah satu sikap dalam rangka melakukan ritual Tantrayana, khususnya bertujuan untuk memuja dewa yang tinggal di Biaro Bahal 1.

Agama Hindu masuk dan berkembang di situs Bumiayu sekitar abad ke-9 Masehi. Hal ini terlihat dari arca-arca dari Candi Bumiayu 1 yang mendapat pengaruh gaya seni Jawa Tengah sejak abad ke-9 Masehi. Arca-arca sebagian besar memiliki kesamaan dengan arca-arca periode Jawa Tengah, yaitu diwujudkan dalam sikap santa (tenang) (Suleiman 1980: 375). Selanjutnya, aliran Tantrayana berkembang di situs Bumiayu, arca-arca digambarkan krodha (menyeramkan). Umat Hindu melakukan ritual Tantrayana dengan memuja Siwa Bhairawa beserta saktinya yaitu Dewi Bhairawa.

Penguasa Bumiayu pada masa itu menganut Tantrayana dengan tujuan untuk membendung pasukan Kertanegara yang melakukan ekspedisi Pamalayu ke Sumatera. Ekspedisi Pamalayu adalah ambisi Raja Kertanegara dari Kerajaan Singhasari yang bertujuan untuk menaklukkan kerajaan-kerajaan Sumatera sehingga dapat memperkuat pengaruhnya di Selat Malaka yang merupakan jalur ekonomi dan politik. Ekspedisi ini juga bertujuan untuk menghadang pengaruh kekuatan Mongol yang hampir menguasai seluruh daratan Asia. Pengiriman pasukan ke Sumatera dilakukan pada tahun 1275 di bawah pimpinan Kebo Anabrang. Pada tahun 1286 Bhumi Melayu dapat ditundukkan. Selanjutnya, Kertanegara mengirim kembali utusannya yang dipimpin rakyan maha mantri dwayabrahma untuk membawa arca Amoghapasa sebagai tanda persahabatan dan hubungan diplomatik dengan Kerajaan Dharmasraya yang saat itu rajanya bernama Sri Maharaja Srimattribhuwanaraja Mauliwarmmadewa. Pada tahun 1284, raja Kertanegara juga berhasil menaklukkan Bali dan membawa rajanya sebagai tawanan menghadap ke Singhasari. Kertanegara meninggal tahun 1292 Masehi, terbunuh akibat pemberontakan Jayakatwang. Dalam bidang agama, Kertanegara memperkenalkan penyatuan agama Hindu dan Siwa dengan agama Buddha Tantrayana. Oleh karena itu, dalam Pararaton, ia disebut Bhatara Siwa Buddha. Menurut kitab Negarakertagama, 
ia telah menguasai ajaran Hindu dan Buddha, gelar keagamaannya adalah Jnanabajreswara, sedangkan dalam prasasti Tumpang ia bergelar Sri Jnaneswarabajra. Kertanegara diwujudkan dalam patung Jina Mahakshobhya, simbol penyatuan dari Siwa dan Buddha, masyarakat mengenalnya sebagai patung Joko Dolog.

\section{PENUTUP}

Agama Hindu pada mulanya muncul dan berkembang di situs Bumiayu sekitar abad ke-9 Masehi. Arca-arca yang dipuja oleh umatnya digambarkan dalam bentuk santa (tenang) seperti arca Siwa Mahadewa, arca Agastya, arca Tokoh 1, arca leluhur, dan arca Nandi. Berbeda halnya dengan arca-arca yang ditemukan pada Candi
Bumiayu 3 yang digambarkan dalam wujud seram, seperti arca Siwa Bhairawa, arca Dewi Bhairawi, arca makhluk gana, dan arca dwalapara. Hal ini menunjukkan situs Bumiayu selanjutnya mendapat pengaruh aliran Tantrayana. Penggambaran arca dengan wajah seram bertujuan memberi rasa takut bagi setiap orang yang melihatnya sehingga musuh tidak berani menyerang dan menghancurkan Bumaiyu.

Pemeluk Tantrayana dari situs Bumiayu memuja Dewa Bhairawa beserta saktinya (Bhairawi), yang arcanya ditemukan pada Candi Bumiayu 3. Pendiri bangunan Candi Bumiayu melakukan upacara Tantrayana dengan tujuan untuk menghadang pasukan Singhasari yang melakukan ekspedisi Pamalayu ke Sumatera pada tahun 1275 Masehi.

\section{DAFTAR PUSTAKA}

Budisantoso, Tri Marhaeni. 2000. "Analisis Candi Bumiayu 3". Berita Penelitian Arkeologi Balai Arkeologi Palembang 5: 1-32.

Ferdinandus, Peter. 1993."Peninggalan Arsitektur dari situs Bumiayu, Sumatera Selatan". Amerta 13: 33-38.

Kartoatmodjo, M.M. Soekarto. 1993. Temuan Prasasti Boom Baru di Sumatera Selatan an Masalah Taman Sri Ksetra dari Kerajaan Sriwjaya. Palembang: Museum Negeri Provinsi Sumatera Selatan Balaputadewa. Magetsari, Nurhadi. 1997. "Candi Borobudur Rekonstruksi Agama dan Filsafatnya". Disertasi. Depok: Universitas Indonesia.

Satari, Sri Soejatmi. 2002. Sebuah Situs Hindu di Sumatera Selatan: Temuan Kelompok Candi dan Arca di Bumiayu. Jakarta: Pusat Penelitian Arkeologi dan Ecole Francaised'Extreme-Orient.

Siregar, Sondang M. 2001. "Tantrayana di Sumatera". Siddhayatra 6 (1): 7-12. . 2002. "Topeng-Topeng Tanah Liat dari Candi Bumiayu 3." Siddhayatra 7(1): 1-4.
.2005. "Kompleks Percandian Bumiayu". Berita Penelitian Arkeologi Balai Arkeologi Palembang 12: 1-25.

Suleiman, Satyawati. 1980. "Studi lkonografi Masa Sailendra di Jawa dan Sumatera". HIm. 375391 dalam Pertemuan IImiah Arkeologi cibulan 21-25 Februari 1977. Jakarta: Pusat Penelitian Purbakala dan Peninggalan Nasional.

.1985. "Peninggalan-Peninggalan Purbakala di Padang Lawas." Amerta 2: 23-38.

Surasmi, I Gusti Ayu. 2007. Jejak Tantrayana di Bali. Bali: CV Bali Media Adhikara.

Susanto, R.M. 1998. "Beberapa Bentuk Penjaga Candi." Berkala Arkeologi Sangkhakala III: 15-28.

Utomo, Bambang Budi. 1994. "Menyingkap Lumpur Lematang". HIm. C6-1-12 dalam Sriwijaya dalam Perspektif Arkeologi dan Sejarah. Palembang: Pemerintah Daerah Tingkat 1 Sumatera Selatan. .2011. Kebudayaan Zaman Klasik Indonesia di Batanghari. Jambi: Dinas Kebudayaan dan Pariwisata. 